\title{
Effects of Clove (Caryophyllus aromaticus L.) on the Labeling of Blood Constituents with Technetium-99m and on the Morphology of Red Blood Cells
}

\author{
Severo de Paoli ${ }^{1,2,4,5 *}$, Tania Santos Giani ${ }^{1,2,4}$, Giuseppe Antonio Presta ${ }^{1,2}$, Marcia Oliveira \\ Pereira $^{2,4}$, Adenilson de Souza da Fonseca ${ }^{2,5}$, José Brandão-Neto ${ }^{1}$, Aldo da Cunha \\ Medeiros $^{1}$, Sebastião David Santos-Filho ${ }^{1,2}$ and Mário Bernardo-Filho ${ }^{2,3}$ \\ ${ }^{1}$ Universidade Federal do Rio Grande do Norte; Programa de Pós-Graduação em Ciências da Saúde; Av. General \\ Gustavo Cordeiro de Farias, s/n; 59010-180; severodepaoli@gmail.com; Natal - RN - Brasil. ${ }^{2}$ Universidade do \\ Estado do Rio de Janeiro; Instituto de Biologia Roberto Alcantara Gomes; Departamento de Biofísica e Biometria; \\ Av. 28 de Setembro, 87; fundos; $4^{o}$ andar; Vila Isabel; 20551-030; Rio de Janeiro - RJ - Brasil. ${ }^{3}$ Instituto Nacional \\ do Câncer; Coordenadoria de Pesquisa Básica; Praça Cruz Vermelha, 23; Centro; 20230-130; Rio de Janeiro - RJ \\ - Brasil. ${ }^{4}$ Universidade Estácio de Sá; Rua do Bispo, 83; Rio Comprido; 20261-063; Rio de Janeiro - RJ - Brasil. \\ ${ }^{5}$ Centro Universitário Fundação Educacional Serra dos Órgãos; Faculdades de Odontologia e Fisioterapia; Av. \\ Alberto Torres, 111; Alto; 25964-004; Teresópolis - RJ - Brasil
}

\begin{abstract}
Clove (Caryophyllus aromaticus L.) has been used for clinical procedures. Blood constituents labeled with technetium-99m $(99 m T c)$ are used in nuclear medicine. The aim of this work was to evaluate the effects of clove extract on the labeling blood constituents with $99 m T c$ and on the morphology of red blood cells. Blood samples were incubated with clove, stannous chloride and 99mTc. Plasma, blood cells, insoluble fractions of plasma and blood cells were separated. The radioactivity was counted and percentage of radioactivity (\%ATI) to each blood fraction was calculated. The shape and morphometric parameter (perimeter/area ratio) were evaluated. Clove extract altered significantly $(p<0.05)$ the \%ATI of blood constituents and the shape of red blood cells without modifying the perimeter/area ratio. The results indicate that clove extract presents chemical compounds that interfere with the radiolabeling of blood constituents and alter the morphology of red blood cells by oxidative/chelating actions or interacting with the cellular membrane structure.
\end{abstract}

Key words: Technetium-99m, Blood constituents, Red blood cells, Morphology, Caryophyllus aromaticus L

\section{INTRODUCTION}

Cloves (Caryophyllus aromaticus L, or Syzygium aromaticum) are the aromatic dried flower buds of a tree belonging to the family Myrtaceae. It is native to Indonesia and used as a spice.

The clove tree is an evergreen that grows to a height ranging from 10-20 meters having large oval leaves and crimson flowers in numerous groups of terminal clusters. The flower buds are at first of a pale color and gradually becoming green, after which they develop into a bright red, when they are ready for collecting. Cloves are harvested when 1.5-2 cm long, and consist of a long calyx, terminating in four spreading sepals, and four

\footnotetext{
${ }^{*}$ Author for correspondence
} 
unopened petals which form a small ball in the center (Bisset, 2001).

Species of this family are often used for several medical purposes, including the treatment of gastrointestinal, due to increase hydrochloric acid in the stomach and to improve peristalsis (Kumari, 1991), circulatory disturbances (Saeed and Gilani, 1994) and as anti-carcinogen agent (Banerjee et al., 2006).

Clove has been used in humans for dentistry applications for over two thousand years to alleviate the pain of toothache and also widely used to disinfect root canals in temporary fillings and as an oral anesthetic (Duke, 1985).

Eugenol has pronounced antiseptic and anaesthetic properties (Chaieb et al., 2007). Other constituents of the clove are acetyl eugenol, betacaryophylline, vanillin, crategolic acid, tannins, gallotannic acid, methyl salicylate, flavanoids (eugenin, kaempferol, rhamnetin, and eugenitin), triterpenoids (oleanolic acid, stigmasterol and campesterol) and several sesquiterpenes (Kramer, 1985; Musenga et al., 2006).

Eugenol is known to inhibit the growth of bacteria and is a natural antibiotic (Suresh-Babu and Madhavi, 2001) with broad antimicrobial activities against gram-positive, gram-negative and acid fast bacteria, as well as fungi (Bisset, 1994; Lueng and Foster, 1996).

Red blood cells labeled with technetium-99m (99mTc-RBC) are widely used in clinical nuclear medicine for several important applications (Wong et al., 2004; Jin et al., 2004; Zaman et al., 2004; Artiko et al., 2004; Harel et al., 2005; Verdu et al., 2005; Olds et al., 2005).

The labeling of RBC with $99 \mathrm{mTc}$ has been used as assay to evaluate the properties of different chemical agents (Abreu et al., 2006; Fonseca et al., 2007). The radiolabeling depends on the presence of a reducing agent and stannous chloride is widely utilized. This technique is easily carried out and produces a better and well-controlled product (Harbert et al., 1996; Saha, 2004).

The morphological analysis of the RBC has been of importance in the investigations of diseases (Bielory, 2004) and to evaluate the effects of natural products on membrane structures (Oliveira et al., 2003).

The aim of this work was to evaluate in vitro, the effects of clove on the labeling blood constituents with $99 \mathrm{mTc}$ and on the morphology of red blood cells.

\section{MATERIALS AND METHODS}

\section{Animals}

All the experimental procedures followed the Ethical Guidelines of the Instituto de Biologia Roberto Alcantara Gomes, Universidade do Estado do Rio de Janeiro with the protocol number CEA/115/2006.

The animals were kept under environmental conditions $\left(25 \pm 2{ }^{\circ} \mathrm{C}, 12 \mathrm{~h}\right.$ of light/dark cycle), water ad libitum and normal diet. Heparinized whole blood was withdrawn by cardiac puncture from adult male Wistar rats under anesthesia by sodium thiopental, $40 \mathrm{mg} / \mathrm{kg}$ of weight $(\mathrm{n}=12,3$ months, $245 \pm 35 \mathrm{~g}$ ).

\section{Clove extract preparation}

Dry clove flowers (Caryophyllus aromaticus L) (1 g) (Fumel Comercial e Industrial Ltda., lot number 12, December 2006, validity December 2007) were triturated and $1 \mathrm{~g}$ of the triturate was mixed with $10 \mathrm{ml}$ of $0.9 \% \mathrm{NaCl}$ solution (saline). After that, the mixture was boiled at $100{ }^{\circ} \mathrm{C}$ and filtered through filter paper (Aldrich Chemical Co, $11 \mathrm{~cm}$, Lot number $\mathrm{k} 932$ ). The filtered solution was considered $100 \mathrm{mg} / \mathrm{ml}$ of aqueous clove extract.

\section{Spectrophotometric measurements}

A spectrophotometric analysis (Analyser, $800 \mathrm{M}$, São Paulo, Brazil) of the extract at $10 \mathrm{mg} / \mathrm{ml}$ was carried out. The absorbance at $480 \mathrm{~nm}$ was considered the marker of the quality control of this extract. All the prepared extracts to be used in the experimental procedures had an optical density of $0.49 \pm 0.01$ (Figure 1).

\section{Labeling of blood constituents with 99mTc}

Samples of whole blood $(0.5 \mathrm{ml})$ were incubated with $100 \mu \mathrm{l}$ clove extract at different concentrations $(0,6.5,12.5,25,50$ and 100 $\mathrm{mg} / \mathrm{ml}$ ) for 1 hour. After that, $0.5 \mathrm{ml}$ of a freshly prepared stannous chloride solution $\left(\mathrm{SnCl}_{2}, 1.2\right.$ $\mu \mathrm{g} / \mathrm{ml}$, Sigma Chemical Co. St Louis, USA) was added. Then, $100 \mu \mathrm{l}$ of $99 \mathrm{mTc}(3.7 \mathrm{MBq}$ ) were added and the incubation continued for another 10 minutes. These samples were centrifuged $(1500$ rpm, 5 minutes) and plasma (P) and blood cells (BC) were separated. Samples $(20 \mu 1)$ of P and BC were also precipitated with $1 \mathrm{ml}$ of trichloroacetic acid $(5 \%)$ and soluble (SF) and insoluble (IF) fractions were obtained. The radioactivity (\% ATI) in $\mathrm{P}, \mathrm{BC}$, IF-P, SF-P, IF-BC and SF-BC was 
determined in a well gamma counter (Clinigamma, gamma counter, Packard Instrument Company, mod C5002, USA). The percentage of incorporated radioactivity (\% ATI) was calculated as described previously (Bernardo-Filho et al., 1986).

\section{Morphological evaluation}

Blood samples $(n=5)$ for each extract concentration) were incubated with clove extract at different concentrations $(6.5,12.5,25,50$ and $100 \mathrm{mg} / \mathrm{ml}$ ) for 1 hour. After that, blood smears $(\mathrm{n}=5$, for each extract concentration) were prepared, dried at room temperature and stained by May-Grünwald-Giemsa method (Barcia, 2007). Briefly, the blood smears were fixed with methanol for 5 minutes, then stained with Giemsa (azure eosin methylene blue solution) for 10 minutes and washed in water to remove excess of stain. The slides were dried at room temperature. These stained glass slides were analyzed by optical microscopy, morphometric measurements (perimeter and area) were performed by a software Image pro plus (Cibernetics, USA) to a total of five fields per each slide and the perimeter/area ratios were calculated.

\section{Statistical analysis}

Data are reported as means \pm standard deviation of $\%$ ATI and perimeter/area ratio and they were compared between the treated and control group by One-way analysis of variance - ANOVA, followed by Bonferroni post test with a $p<0.05$ as significant level. InStat Graphpad software was used to perform statistical analysis (GraphPad InStat version 3.00 for Windows 95, GraphPad Software, San Diego, California, USA).

\section{RESULTS}

Fig. 1 shows the absorption spectrum of the clove extract used in the experiments. The pattern of the absorption spectra presents the highest measure of the optical density $(0.489 \pm 0.013)$ at $480 \mathrm{~nm}$. This parameter has permitted to control the conditions to prepare the extracts and has been used as a marker.

Table 1 shows the effect of different concentrations of the clove extract on the distribution of radioactivity between cellular and plasma compartments. The clove extract used decreased significantly $(\mathrm{p}<0.05)$ the $\%$ ATI on the cellular compartment from $96.96 \pm 1.06$ to $44.45 \pm 2.87$.

Table 2 shows the effect of different concentrations of the clove extract on the fixation of $99 \mathrm{mTc}$ on plasma proteins. The clove extract decreased significantly $(\mathrm{p}<0.05)$ the fixation of the $99 \mathrm{mTc}$ on the plasma proteins from $64.28 \pm 7.55$ to $15.11 \pm 0.63$.

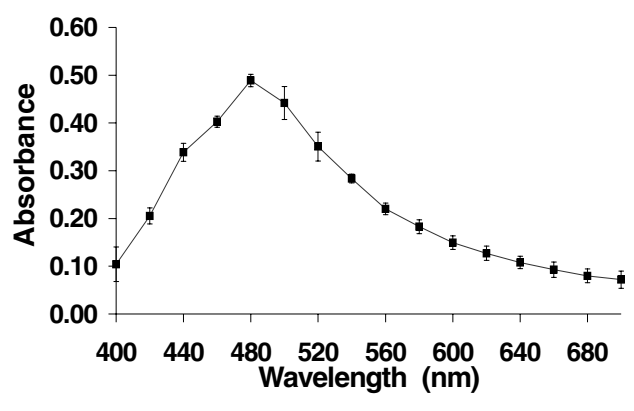

Figure 1 - Absorption spectrum of the clove extract 
Table 1 - Effect of different concentrations of a clove extract on the distribution of radioactivity in cellular compartment.

\begin{tabular}{lc}
\hline Clove extract $(\mathbf{m g} / \mathbf{m l})$ & \% ATI in Cellular compartment \\
\hline 0.0 & $96.96 \pm 1.06$ \\
6.5 & $56.89 \pm 3.66$ \\
12.5 & $55.67 \pm 4.95$ \\
25 & $54.21 \pm 1.86$ \\
50 & $53.94 \pm 0.80$ \\
100 & $44.45 \pm 2.87 *$ \\
\hline
\end{tabular}

Blood samples were incubated with clove extract at different concentrations. After that, the labeling of blood constituents with $99 \mathrm{mTc}$ was performed. The samples were centrifuged and aliquots of blood cells were separated. The radioactivity in these fractions was determined and the percentage of incorporated radioactivity (\% ATI) was determined. $(*)$ p $<0.05$ when compared to control.

Table 2 - Effect of different concentrations of the clove extract on the labeling of plasma proteins

\begin{tabular}{lc}
\hline Clove extract $(\mathbf{m g} / \mathbf{m l})$ & \% ATI in Plasma proteins \\
\hline 0.00 & $73.94 \pm 1.04$ \\
6.5 & $33.09 \pm 2.82$ \\
12.5 & $33.04 \pm 3.97$ \\
25 & $28.15 \pm 3.17$ \\
50 & $19.59 \pm 5.75$ \\
100 & $15.11 \pm 0.63 *$ \\
\hline
\end{tabular}

Blood samples were incubated with clove extract for 1 hour. After that, the labeling of blood constituents with $99 \mathrm{mTc}$ was performed. Aliquots of plasma were precipitated in trichloroacetic acid. The radioactivity in these fractions was determined and the percentage of incorporated radioactivity (\% ATI) was determined. $(*) \mathrm{p}<0.05$ when compared to control.

Table 3 shows the effect of different concentrations of clove extract on the fixation of ${ }^{99 \mathrm{~m}} \mathrm{Tc}$ on proteins of blood cells. The results show that the clove extract decreased significantly $(p<0.05)$ the radioactivity fixation on the cellular proteins from $91.39 \pm 1.17$ to $71.16 \pm 3.87$.
Figs. 2 and 3 represent the photomicrographies of blood smears from blood samples treated with saline $(0.9 \% \mathrm{NaCl})$ and clove extract at the higher concentration used $(100 \mathrm{mg} / \mathrm{ml})$, respectively. The qualitative comparison between these figures indicates that clove extract alters the morphology of RBC.

Table 3 - Effect of different concentrations of the clove solution on the labeling of cells proteins

\section{Clove extract $(\mathbf{m g} / \mathrm{ml})$}

\begin{tabular}{lc}
\hline 0.0 & $91.39 \pm 1.17$ \\
6.5 & $82.03 \pm 3.38$ \\
12.5 & $79.65 \pm 2.27$ \\
25 & $76.01 \pm 3.05$ \\
50 & $73.53 \pm 3.47$ \\
100 & $71.16 \pm 3.87 *$ \\
\hline
\end{tabular}

Blood samples were incubated with clove extract for 1 hour. After that, the labeling of blood constituents with $99 \mathrm{mTc}$ was performed. Aliquots of blood cells were precipitated in trichloroacetic acid. The radioactivity in these fractions was determined and the percentage of incorporated radioactivity (\% ATI) was determined. $(*)$ p $<0.05$ when compared to control. 


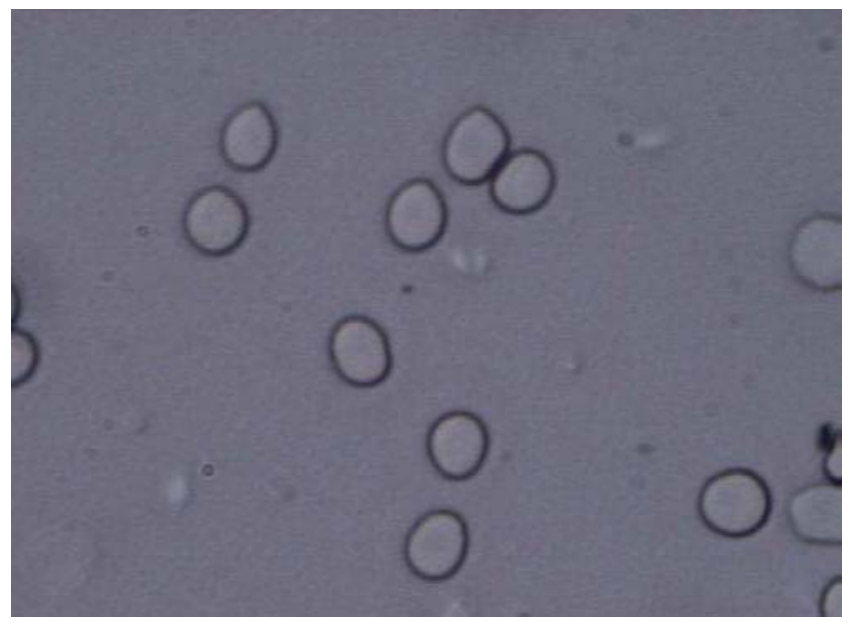

Figure 2 - Photomicrography of blood smear from blood incubated with saline (control). Blood samples were incubated with $0.9 \% \mathrm{NaCl}$ for 1 hour. Blood smears were prepared and stained by MayGrünwald-Giemsa method. The slides were analyzed by optical microscopy (x1000)

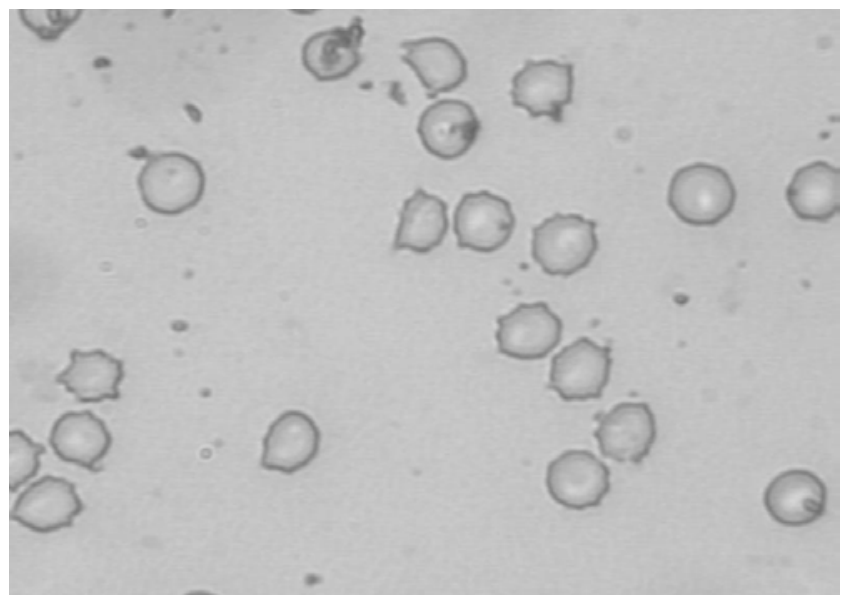

Figure 3 - Photomicrography of blood smear from blood incubated with clove extract. Blood samples were incubated with clove extract $(100 \mathrm{mg} / \mathrm{ml})$ for 1 hour. Blood smears were prepared and stained by May-Grünwald-Giemsa method. The slides were analyzed by optical microscopy (x1000)

Fig. 4 shows the perimeter/area ratio of $\mathrm{RBC}$ treated with different concentrations of clove extract. The perimeter/area ratio had significantly increased $(\mathrm{p}<0.05)$ only to blood samples incubated with clove extract at the higher concentration. 


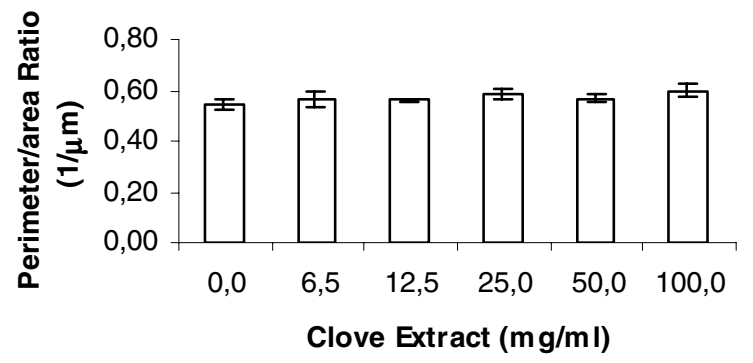

Figure 4 - Effect of clove extract on the perimeter/area ratio of RBC. Morphometric measurements of perimeter/area of RBC from blood smears with a total of five fields per each slide and five slides to each extract were evaluated. The software Image pro plus, media Cibernetics, USA) was used to these evaluations

\section{DISCUSSION}

Some authors have reported that nuclear medicine procedures could be altered by medication treatments that the patient is undergoing. (Hesslewood and Leung, 1994; Owunwanne et al., 1995; Sampson, 1999). Blood constituents labeled with $99 \mathrm{mTc}$ have been used in several clinical examinations (Saha, 2004) and also as an experimental assay on an attempt to verify the effect of drugs (Fonseca et al., 2007). This experimental model has permitted to obtain relevant information about properties of various chemical compounds (synthetic and natural) (Abreu et al., 2006; Fonseca et al., 2007).

The analysis of the results shown in tables 1,2 and 3 indicates that there was an important alteration on the labeling of the blood constituents with ${ }^{99 \mathrm{~m}} \mathrm{Tc}$ when the incubation with clove extract was made in vitro at highest concentration used.

These results could be explained, at least in part, by a possible oxidant and citotoxic property of the chemical compounds that are present in the clove solution (Schmalz et al., 2000). These compounds could oxidize the stannous ions that are necessary to the reduction of the pertechnetate ion, as suggested by other authors to several natural products, as Maytemus icilifolia (Oliveira et al., 2000), Ginkgo biloba (Moreno et al., 2002), Paullinia cupana (Oliveira et al., 2002) and Mentha crispa (Santos-Filho et al., 2004).

Other possible explications would be the actions of the clove on the ions transport systems and alteration of the RBC membrane structure. In fact, some flavoids were described as capable of interacting with ions transport channels in membrane (Morales et al., 1994; Re et al., 1999).
Bratel et al., (1998) have reported that extractable components of some commonly used root canal sealing materials may interfere with immunocompetent cells in vitro. In addition, the antibacterial effect of compounds presents in clove extract could be related to action on bacterial membrane.

Changes in the optic disc structure and thickness of retinal nerve fiber layer in chronic ocular hypertensive monkeys (Shimazawa et al., 2006), the relationship between infarct-related artery stenosis and capillary density (Prech et al., 2005) and the effects of two sex hormones on normal mammal gland of female rats (Pompei et al., 2005) are several important findings obtained by morphometric measurements. Oliveira et al. (2003) showed possible alterations by morphometric analysis of RBC from blood treated with natural products.

The qualitative morphologic analysis indicated that clove extract induce alterations on shape of RBC (Fig. 2). However, this finding was not confirmed by quantitative analysis by mophometric measurements indicating no effect of clove extract at the higher concentration (100 $\mathrm{mg} / \mathrm{ml}$ ) on the perimeter/area ratio of RBC (Figure $3)$.

The morphology of RBC is influenced by function of ion transport systems in membrane (Lew and Bookchin, 2005). Chemical compounds in clove extract may interact with these systems and alter the morphology of RBC observed in this study. This hypothesis could be in agreement with the results of the distribution of radioactivity in cellular compartment (Table 1).

In conclusion, the results obtained in this work indicate that the aqueous clove extract studied 
present chemical compounds that interfere with the labeling of blood constituents with $99 \mathrm{mTc}$ and alter the morphology of RBC by oxidative/chelating actions or interacting with the cellular membrane structure.

\section{ACKNOWLEDGEMENTS}

We are grateful for the biologist Mario Pereira (UERJ) for his technical support and to Mr. Carlos Brown Scavarda (B. A., University of Michigan) for the English language revision. Financial support: CNPq, CAPES and UERJ.

\section{RESUMO}

O cravo-da-índia (Caryophyllus aromaticus L.) tem sido usado em tratamentos clínicos. Constituintes sangüíneos marcados com tecnécio$99 \mathrm{~m}(99 \mathrm{mTc})$ são usados em medicina nuclear $\mathrm{O}$ objetivo foi avaliar os efeitos de um extrato de cravo-da-índia na marcação de constituintes sangüíneos com 99mTc e na morfologia das hemácias. Amostras de sangue foram incubadas com cravo-da-índia, cloreto estanoso e $99 \mathrm{mTc}$. Plasma, células sangüíneas, frações insolúveis do plasma e das células sangüíneas foram separadas. A porcentagem de radioatividade incorporada (\% ATI) nestas frações foi calculada. Forma e relação perímetro/área das hemácias foram avaliadas. O extrato de cravo-da-índia alterou significativamente $(p<0,05)$ a radiomarcação de constituintes sangüíneos e qualitativamente a forma das hemácias. Não foram obtidas alterações na relação perímetro/área hemácias. Os resultados indicam que o extrato de cravo-da-índia apresenta compostos que interferem com a radiomarcação de constituintes sangüíneos e alteram a morfologia de células sangüíneas através de ações oxidativas/quelantes ou interagindo com a estrutura da membrana celular.

\section{REFERENCES}

Abreu, P. R.; Almeida, M. C.; Bernardo, R. M., Bernardo; L. C., Brito, L. C.; Garcia, E. A.; Fonseca, A. S.; and Bernardo-Filho, M. (2007), Guava extract (Psidium guajava) alters the labelling of blood constituents with technetium-99m. J. Zhejiang Univ. Sci. B., 7, 429-35.
Artiko, V.; Obradovic, V.; Petrovic, M.; Perisic-Savic, M.; and Suvajdzic, N. (2004), Hemangioma of the spleen confirmed by blood pool scintigraphy. Clin. Nucl. Med., 29, 670-671.

Banerjee, S.; Panda, C. K.; and Das, S. (2006), Clove (Syzygium aromaticum L.), A potential chemopreventive agent for lung cancer. Carcinogenesis, 8, 1645-1654.

Barcia, J. J. (2007), The Giemsa stain: its history and applications. Int. J. Surg. Pathol. 15, 292-296.

Bernardo-Filho, M.; Caniné, M. S.; Lopes, R. L. F.; and Boasquevisque, E. M. (1986), Effect of temperature on the "in vitro" labeling of red blood cells with technetium-99m. Braz. Arch. Biol. Technol., 29, 407412.

Bielory, L. (2004), Complementary and alternative interventions in asthma, allergy and immunology; Ann. Allergy. Asthma. Immunol., 93, 45-54.

Bisset, N. G. (1994), Herbal Drugs and Phytopharmaceuticals: A Handbook for Practice. Translad, ed. Boca Raton CRC Press, London, pp. 566.

Bisset, N. G. (2001), Herbal Drugs and Phytopharmaceuticals: A Handbook for Practice, ed. CRC Press, London, pp. 566.

Bratel, J.; Jontell, M.; Dahlgren, U.; and Bergenholt, G. (1998), Effects of root canal sealers on immunocompetent cells in vitro and in vivo. Int. Endod. J., 31, 178-188.

Chaieb, K.; Hajlaoui, H.; Zmantar, T.; Kahla-Nakbi A. B.; Rouabhia, M.; Mahdouani, K.; and Bakhrouf, A. (2007), The chemical composition and biological activity of clove essential oil, Eugenia caryophyllata (Syzigium aromaticum L. Myrtaceae): a short review. Phytother. Res., 6, 501-506.

Duke, J. A. (1985), Handbook of Medicinal Herbs, ed. CRC Press, New York, pp. 468 - 469.

Fonseca, A. S.; Frydman, J. N.; Rocha, V. C.; and Bernardo-Filho, M. (2007), Acetylsalicylic acid decreases the labeling of blood constituents with technetium-99M. Acta Biol. Hung., 2, 187-198.

Harbert, J. C.; Eckelman, W. C.; and Neumann, R. D. (1996), Nuclear Medicine of Diagnosis and Therapy, ed. Thieme, New York.

Harel, F.; Dupuis, J.; Benelfassi, A.; Ruel, N.; and Gregoire, J. (2005), Radionuclide plethysmography for non-invasive evaluation of peripheral arterial blood flow. Am. J. Physiol Heart. Circ. Physiol., 289, 258-262.

Hesslewood, S. and Leung, E. (1994), Drug interactions with radiopharmaceuticals. Eur. J. Nucl. Med. 21, 348-356.

Jin, R. B.; Ma, X. L.; Wen, J. L.; and Tang, W. J. (2004), Application of radionuclide imaging to hepatic impact injury in rabbits. Chin. J. Traumatol. 7, 45-48.

Kramer, R. E. (1985), Antioxidants in clove. J. Am. Oil Chem. Soc. 62, 111-113. 
Kumari, M. V. (1991), Modulatory influences of clove (Caryophyllus aromaticus, L) on hepatic detoxification systems and bone marrow genotoxicity in male Swiss albino mice. Cancer Lett. 60, 67-73.

Lew, V. L. and Bookchin, R. M. (2005), Ion transport pathology in the mechanism of sickle cell dehydration. Physiol. Rev. 1, 179-200.

Lueng, A. Y. and Foster, S. (1996), Encyclopedia of common natural ingredients: used in food, drugs and cosmetic, ed. John Wiley and Sons, New York.

Morales, M. A.; Tortoriello, J.; Meckes, M.; Paz, D.; and Lozoya, X. (1994), Calcium-antagonist effect of quercetin and its relation with the spasmolytic properties of Psidium guajava L. Arch. Med. Res. 25, 17-21.

Moreno, S.R.F.; Diré, G.; Freitas, R.S.; Farah, M.B.; Lima-Filho, G.L.; Rocha, E.K.; Jales, R.L.C. and Bernardo-Filho, M. (2002), Effect of Ginkgo biloba on the labeling of blood elements with technetium99m: in vitro study. Rev. Bras. Farmacogn., 12:623.

Musenga, A.; Ferranti, A.; Saracino, M. A.; Fanali, S.; and Raggi, M. A. (2006), Simultaneous determination of aromatic and terpenic constituents of cloves by means of HPLC with diode array detection. J. Sep. Sci. 9, 1251-1258.

Olds, G. D.; Cooper, G. S.; Chak, A.; Sivak, M. V. J.; Chitale, A. A.; and Wong, R. C. (2005), The yield of bleeding scans in acute lower gastrointestinal hemorrhage. J. Clin. Gastroenterol. 39, 273-277.

Oliveira, J. F.; Braga, A. C. S.; Ávila, A. S. R.; Araújo, A. C.; Cardoso, V. N.; Bezerra, R. J. A .C. and Bernardo-Filho, M. (2000), Assessment of the effect of Maytemus icilifolia extracts on the labeling of red blood cells and plasma proteins with technetium99m. J.Ethnopharmacol. 72, 179-184.

Oliveira, J. F.; Ávila, A. S.; Braga, A. C. S.; Oliveira, M. B. N.; Boasquevisque, E. M.; Jales, R. L.; Cardoso, V. N. and Bernardo-Filho, M. (2002), Effect of extract of medicinal plants on the labeling of blood elements with Technetium-99m and on the morphology of red blood cells: a study with Paullinia Cupana. Fitoterapia. 73, 305-312.

Oliveira, J. F.; Oliveira, M. B.; Ávila, A. S.; Braga, A. C.; Catanho, M, T. J. A.; Jales, R. L.; Cardoso, V. N. and Bernardo-Filho, M. (2003), Assessment of the effect of Fucus vesiculosus extract on the labeling of blood constituents with technetium-99m and the histological modifications on the shape of the red blood cells. Food. Chem. Toxicol., 41, 15-20.

Owunwanne, A.; Patel, M.; Sade, K. S. (1995), The

Handbook of Radiopharmaceuticals, ed. Chapman and Hall, London.
Pompei, L. M.; Carvalho, F. M.; Ortiz, S. C.; Motta, M. C.; Cruz, R. J. and Melo, N. R. (2005), Morphometric evaluation of effects of two sex steroids on mammary gland of female rats. Maturitas., 5, 370-379.

Prech, M.; Grajek, S.; Marszalek, A.; Lesiak, M.; Jemielity, M.; Araszkiewicz, A.; Mularek-Kubzdela, T. and Cieslinski, A. (2005), Chronic infarct-related artery occlusion is associated with a reduction in capillary density. Effects on infarct healing. Eur. J. Heart. Fail., 8, 373-380.

Re, L.; Barocci, S.; Capitani, C.; Vivani, C.; Ricci, M.; Rinaldi, L.; Paolucci, G.; Scarpantonio, A.; LeonFernandez; O. S. and Morales, M. A. (1999), Effects of some natural extracts on the acetylcholine release at the mouse neuromuscular junction. Pharmacol. Res.,39, 239-245.

Saeed, S. and Gilani, A. H. (1994), Antithrombotic activity of clove oil. J Pak Med Assoc. 44, 112-115.

Saha, G. B. (2004), Fundamentals of nuclear pharmacy, ed. Springer, New York.

Sampson, C. B. (1999), Textbook of Radiopharmacy

Theory and Practice, ed. Gordon and Breach,

Amsterdam.

Santos-Filho, S. D.; Diré, G. L.; Lima, E.; Oliveira, M. N. and Bernardo-Filho, M. (2004), Effect of Mentha crispa extract on the labeling of blood elements with technetium-99m: A possible evaluation of free radicals. J. Biol. Sci., 8, 266-70.

Schmalz, G.; Hoffmann, M.; Weis, K. and Schweikl, H. (2000), Influence of albumin and collagen on the cell mortality evoked by zinc oxide-eugenol in vitro $J$ Endod., 2, 284-287.

Shimazawa, M.; Taniguchi, T.; Sasaoka, M. and Hara, H. (2006), Nerve fiber layer measurement using scanning laser polarimetry with fixed corneal compensator in normal cynomolgus monkey eyes. Ophthalmic Res., 38, 1-7.

Suresh-Babu, S. and Madhavi (2001), Green Remedies, ed. Pustak Mahal, Delhi, pp. 74 -75.

Verdu, J.; Martinez, A.; Anton, M. A.; Munozm J. M.; Riera, M.; Jover, R. and Caballero, O. (2005), Increased thallium-201 uptake and Tc-99m red blood cell accumulation in hemangioma. Clin. Nucl. Med., 30, 25-6.

Wong, K. T.; Beauvais, M. M.; Melchior, W. R. and Snyder, S. P. (2004), Enhanced liver uptake of Tc99m-labelled RBCs during gastrointestinal bleed scintigraphy using transfused RBCs compared with autologous RBCs. Clin. Nucl. Med.,29, 522-3.

Zaman, M. U; Hussain, R.; Sajjad, Z. and Ahmad, M. N. (2004), Localization of upper GI bleed on delayed imaging with ${ }^{99 \mathrm{~m}} \mathrm{Tc}$ tagged RBC angiogram. J. Pak. Med. Assoc., 254, 490-491. 